\title{
Impact of Armored Shorelines on Shore-Zone Fish Density in a Mid-Atlantic, USA, Estuary: Modulation by Hypoxia and Temperature
}

\author{
Richard G. Balouskus ${ }^{1}$ • Timothy E. Targett ${ }^{1}$ \\ Received: 19 September 2016/Revised: 2 April 2017 /Accepted: 27 April 2017 /Published online: 23 May 2017 \\ (C) The Author(s) 2017, corrected publication 2019
}

\begin{abstract}
Anthropogenic modifications of estuarine environments, including shoreline hardening and corresponding alteration of water quality, are accelerating worldwide as human population increases in coastal regions. Estuarine fish species inhabiting temperate ecosystems are adapted to extreme variations in environmental conditions including water temperature, salinity, and dissolved oxygen across seasonal, daily, and hourly time scales. The present research utilized quantitative sampling to examine the spatiotemporal distribution of shorezone estuarine fish species in association with four unique shoreline types across a range of water temperature and dissolved oxygen conditions. Fish were collected from the intertidal and shallow subtidal region of four shoreline types, Spartina alterniflora marsh, Phragmites australis marsh, riprap, and bulkhead, in the summer and fall of 2009 and 2010. Analyses were performed to (1) compare mean fish density among shoreline types across all water conditions and (2) explore relationships of the complete fish assemblage, three functional species groupings, and two fish species (Fundulus heteroclitus and Menidia menidia) to unique shoreline/water conditions. Significantly greater mean fish densities were found along $S$. alterniflora shorelines than armored shorelines. Several metrics including fish density, species richness, and occurrence rates suggest $S$. alterniflora shorelines may
\end{abstract}

Communicated by Josianne G. Støttrup

Electronic supplementary material The online version of this article (doi:10.1007/s12237-017-0258-6) contains supplementary material, which is available to authorized users.

Richard G. Balouskus rbalousk@udel.edu

1 College of Earth, Ocean and Environment, School of Marine Science and Policy, University of Delaware, Lewes, DE 19958, USA serve as a form of refuge habitat during periods of low dissolved oxygen and high temperatures for various species, particularly littoral-demersal species including $F$. heteroclitus. Potential mechanisms that could contribute to a habitat providing refuge during adverse water quality conditions include tempering of the adverse condition (decreased temperatures, increased dissolved oxygen), predation protection, and increased foraging opportunities.

Keywords Intertidal $\cdot$ Shoreline hardening $\cdot$ Shoreline armoring $\cdot$ Estuary-dependent $\cdot$ Spartina $\cdot$ Phragmites

\section{Introduction}

Temperate estuaries worldwide have experienced a decrease in native vegetation within the past several decades, while invasive grass species and several types of shoreline armoring including bulkhead and riprap structures have become more common (Lee et al. 2006; USGS 2011, 2013; Hazelton et al. 2014; Kettenring et al. 2015). These hardened shorelines and invasive grasses have caused changes in the ecological character of the intertidal zone, particularly in urbanized watersheds (Raichel et al. 2003; Bilkovic and Roggero 2008, Peterson and Lowe 2009). Hypoxia resulting from urban and agricultural runoff-driven eutrophication of coastal estuarine ecosystems is increasing in both temporal and spatial scales worldwide, as the past 65 years has seen a rapid acceleration in the number of occurrences of severe hypoxic and anoxic conditions in estuarine environments (Diaz and Rosenberg 1995; Diaz et al. 2004; Diaz and Rosenberg 2008). In conjunction with altered shorelines and increased hypoxia, urbanizing estuaries are likely to experience increased water temperatures over the next 50 years (IPCC 2014). 
Estuaries, with their varied aquatic habitats, serve as critical nursery grounds for the early life stages of many species of fish (Weinstein 1979; Rakocinski et al. 1992; Peterson and Turner 1994; Peterson et al. 2000). Estuary-resident (species that spend their entire life cycle within an estuary), estuary-dependent (species that utilize estuaries for an obligate portion of their life cycle such as spawning), and transient (non-obligate estuarine inhabitants) fishes serve an important role in estuarine food webs and are instrumental in the movement of organic material within and out of estuarine ecosystems (Kneib et al. 1980; Kwak and Zedler 1997; Deegan et al. 2002). Degradation of estuarine habitat is among the most significant threats to fisheries (Burns 1991; Thomas 1995), as over $70 \%$ of commercial fishery species (Brouha 1993; Waste 1996) and over 66\% of recreational fishery species utilize coastal and estuarine habitats during at least one stage of their life history (Thayer et al. 1996)

Riprap and bulkhead are frequently installed along shorelines in an attempt to reduce erosion and provide storm surge protection for areas of human development. Negative impacts of these structures on populations of fishes, crustaceans, and benthic invertebrates living adjacent to them have been well documented in recent years (Seitz et al. 2006; Strayer et al. 2012; Gittman et al. 2016a, b; Torre and Targett 2016). The work of Bilkovic and Roggero (2008) demonstrated that bulkheads negatively affect the shore-zone environment and related nekton assemblages in large tributaries of Chesapeake Bay.

Disturbance of natural shorelines through the installation of shoreline armoring is one of the primary contributors to the expansion of a non-native genotype of Phragmites australis in the mid-Atlantic region (King et al. 2007). P. australis invasion has led to a displacement of native macrophyte communities, degradation of wildlife habitat, and alteration of ecosystem processes (Weinstein and Balletto 1999; Windham and Meyerson 2003; Minchinton et al. 2006). Dominant estuarine species such as the mummichog (Fundulus heteroclitus) have been shown to be negatively impacted by the spread of $P$. australis that reduces prey density, compared with native marsh, available for resident marsh fishes (Teo and Able 2003a, b; Raichel et al. 2003).

In addition to the physical structure of shore-zones, water quality characteristics including dissolved oxygen (DO) moderate the occurrence and density of estuarine fishes (Boutin and Targett 2013). Hypoxia is any DO below oxygen saturation, and $\mathrm{DO}<2.3 \mathrm{mg} \mathrm{O}_{2} / 1$ is characterized as severe hypoxia, a condition which is harmful to aquatic fauna (USEPA 2000; Diaz 2001; Tyler et al. 2009). A minimum DO concentration of $4.8 \mathrm{mg} \mathrm{O} / 1$ is defined as the growth protective criteria for the most sensitive species in the saltwater faunal community in the
mid-Atlantic region (USEPA 2000). Increased nutrient input, particularly nitrogen, from developed watersheds results in excessive algal growth and is commonly associated with severe hypoxia (Nixon 1995; Valiela et al. 1997; Bricker et al. 1999, 2014).

Fish actively search and select the habitat with the relative highest quality available based on habitat functions and considerations of how those functions change over different temporal scales (Rountree and Able 2007). External conditions such as DO, water temperature, salinity, prey availability, and predation risk influence fish behavior and movement; behavioral avoidance strategies in hypoxic waters, in particular, exhibit situational dependence (Kramer 1987; Eby and Crowder 2002). Field studies frequently demonstrate that abundance and diversity of fishes decline as DO decreases (Breitburg et al. 2001; Eby and Crowder 2002; Tyler and Targett 2007). And that fish have been found to migrate away from hypoxic conditions and return immediately following the onset of increased DO (Tyler and Targett 2007). Distribution of fish at an instantaneous point in time in an ecosystem will also reflect temporary searching and imperfect habitat selection. Estuarine ecosystems provide a mosaic of habitat types with different shore-zone structures (vegetated and armored), DO levels, temperatures, and salinities at any given time. Certain habitats may provide better refuge from hypoxia and excessive water temperature by providing less severe DO or temperature conditions, increased predation protection, or increased foraging opportunities, while other habitats may exacerbate physiological stress (Baltz et al. 1993, Szedlmayer and Able 1996, Halpin 2000, Eby and Crowder 2002).

Understanding how the biophysical structure of estuarine shorelines, in association with water quality conditions, affects the functional value and habitat quality of estuaries for shore-zone biota is important in determining anthropogenic impacts on estuarine systems. The present research used quantitative sampling to examine how estuarine shoreline structure in association with diel-cycling DO and water temperature conditions interacts to affect the assemblage structure and density of estuary-resident and estuary-dependent fishes in tidal marsh creeks of the Delaware Coastal Bays. The objectives of this study were to (1) utilize intensive weekly sampling to examine estuarine fish assemblages and density along four different shoreline types (Spartina alterniflora, P. australis, riprap, and bulkhead) and (2) analyze the interactive impacts of categorical DO and water temperature conditions in association with shoreline type on mean fish density of the whole fish assemblage, three functional groupings of fish species (littoral-demersal, benthivore/piscivore, planktivore), and two highly abundant estuarine species (F. heteroclitus and Menidia menidia). 


\section{Materials and Methods}

\section{Study Area}

The Delaware Coastal Bays are comprised of three major embayments and their respective tributaries and canals (Fig. 1). All three bays are characterized by native fringing S. alterniflora (smooth cordgrass) marsh, the invasive $P$. australis (common reed), and increasing human development (Daiber 1969; Tyler 2005; Boutin and Targett 2013).

Fish sampling and water quality monitoring were conducted in both Indian River and Pepper Creek (Fig. 1). Both tributaries contain high levels of nutrients, particularly nitrogen (DIBEP 1995; Price 1998; T. Jordan unpublished data), largely due to agricultural and residential runoff within the watershed. Both tributaries exhibit severe diel-cycling hypoxia during summer months (Tyler and Targett 2007, 2009). Fish sampling was conducted in an upper and lower region in each tributary in 2009 and 2010. A third tributary region was sampled near the mouth of Indian River (IRLL) during the summer of 2009 (Fig. 1). Each of the four study shoreline types (bulkhead, riprap, $P$. australis, $S$. alterniflora) was present at each sampling region except lower Pepper Creek (PCL) which did not have a $P$. australis shoreline and IRLL which did not have a riprap shoreline. Within each respective sampling region, all sampled shorelines were located within a $0.75-\mathrm{km}$ stretch of creek including both sides of shore.

\section{Fish Sampling}

Seining was conducted weekly to quantify fish abundance and diversity inhabiting the shore-zone and shallow subtidal region in the five tributary regions from August through October in $2009(n=67)$ and May through October in 2010
( $n=239$ ). Fishes occupying each of the four shoreline types were sampled using a 10-m seine with center bag ( $2 \mathrm{~m}$ high; $5 \mathrm{~mm}$ mesh) in 2009 and a $15-\mathrm{m}$ seine with center bag ( $2 \mathrm{~m}$ high; $5 \mathrm{~mm}$ mesh) in 2010. Shoreline types sampled were $\geq 30 \mathrm{~m}$ in length. Individual sections of shoreline where seining occurred are referred to as sampling stations; 23 sampling stations in total were sampled during the summers of 2009 and 2010. Seine hauls sampled areas of $\sim 21$ and $\sim 33 \mathrm{~m}^{2}$ in 2009 and 2010, respectively. Water depths were taken at the landwater interface and at the maximum offshore sampling distance of the seine haul to calculate volume of water seined and, subsequently, fish density (individuals $/ \mathrm{m}^{3}$ ). Because sampling methodologies were identical between nets and years, area and volume swept were accounted for, and as mobility of the fish species sampled is limited, samples between gear and year were pooled for statistical analyses.

Seining was conducted using the following method: One end of the net was placed on shore using a shallow draft boat. The net was unfurled in an arc, $3 \mathrm{~m}$ from shore at its maximum extent, along the shoreline. The far end of the net was then brought to shore. A PVC pole was used to startle fish from the area between the net and shoreline toward the net bag. The two ends of the net were walked together along the shoreline and the net was gathered and fish directed into the bag. The net bag was cinched tight in the water and placed in the boat where the sample was removed and placed in a bucket containing tributary water. The sampling station was immediately seined again, using the same method and the same deployment direction. Fish from the second seine haul were placed into a second bucket. As sediment type and subtidal structure can influence species abundance and assemblage structure (Szedlmayer and Able 1996), all sampling stations were located along areas where substrate ranged from sand to mud, with little to no subtidal structure (e.g., woody debris or rock).

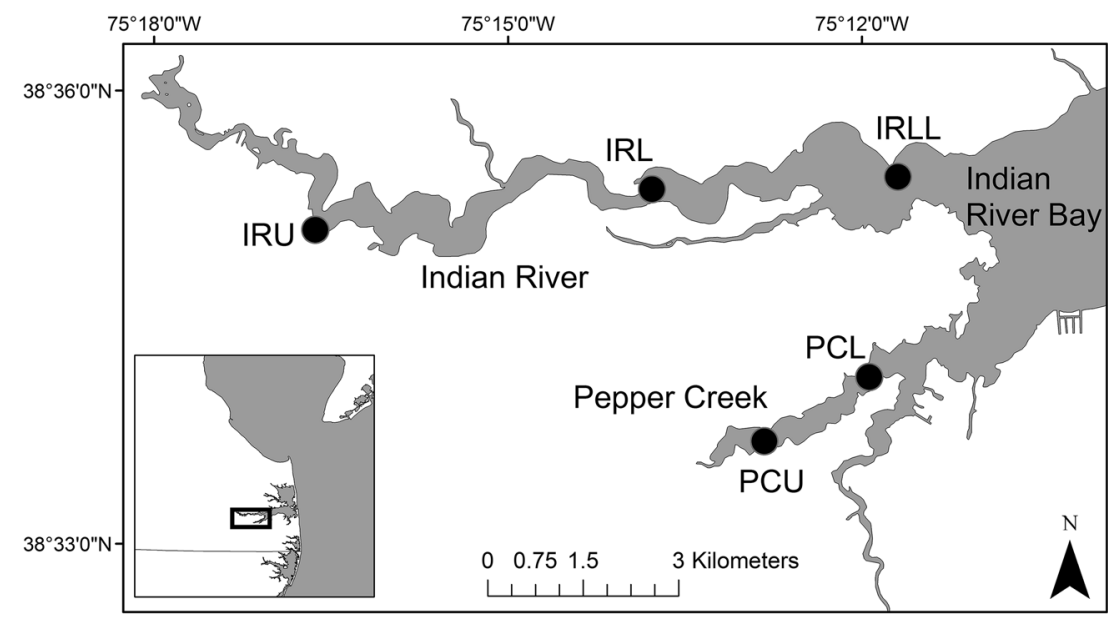

Fig. 1 Indian River and Pepper Creek, tributaries of Indian River Bay, Delaware Coastal Bays, with locations of fish sampling stations in upper Indian River (IRU), lower Indian River (IRL), mouth of Indian River (IRLL) (2009), upper Pepper Creek (PCU), and lower Pepper Creek
$(P C L)$. Multi-parameter sondes were deployed at these locations to continuously measure water temperature, dissolved oxygen $(\mathrm{mg} / \mathrm{l})$, and salinity (psu) throughout the study 
The catch from both seine hauls was combined to form a single sample. All fish were identified, counted, and released adjacent to the shoreline where they were collected. Riprap and bulkhead sites were sampled within $2 \mathrm{~h}$ of high tide. To account for water level and utilization of the marsh surface (Rozas and Minello 1997), S. alterniflora marsh and $P$. australis sites were sampled within $2 \mathrm{~h}$ of high tide when the water level had just reached the marsh edge.

As each of the four shoreline types examined presents unique sampling environments, species-specific response ratios (Z-scores) were estimated for seine hauls along each shoreline type using Leslie depletion models (Seber 2002). For a concurrent related study, Z-scores were determined for $F$. heteroclitus, Morone americana, and $M$. menidia at each of the three shoreline types (marsh, riprap, and bulkhead) (Kornis et al. 2017, supplementary material) using a 20-m beach seine. Proxy Z-score values from these three species were then assigned to each species caught in this study based on similarities in body shape and water column location (Supplement Material A). Z-scores were applied to untransformed abundance data from each sampling event for both the 10 - and 15-m bag seines in order to correct for gear bias in capture efficiency specific to each shoreline type.

\section{Water Quality Monitoring}

YSI model 600XLM multi-parameter sondes were deployed in each of the five study regions (Fig. 1) for continuous monitoring from May through September during 2009 and 2010. Salinity (psu), DO (DO saturation \% and $\mathrm{mg} / \mathrm{l}$ ), $\mathrm{pH}$, and water temperature $\left({ }^{\circ} \mathrm{C}\right)$ were recorded at 15 -min intervals. Sondes were centrally located among sampling stations within each tributary region and positioned just outside the navigation channel. Each sonde was suspended approximately $15 \mathrm{~cm}$ above the substrate using a steel pyramid stanchion.

\section{Data Analyses}

Mean fish density (individuals $/ \mathrm{m}^{3}$ ), corrected for speciesspecific response ratios, was calculated for all fishes along each shoreline type. For the five species with the greatest mean fish density summed across all four shoreline types, two additional analyses were performed: (1) the percentage of a given species' total catch that was collected at each shoreline type (identifying which shoreline is utilized most frequently by the species) and (2) the percentage of total catch at each shoreline type that each species comprised (identifying species that dominated the collections at the specified shoreline type).

A non-parametric one-way repeated measures ANOVA using a bootstrapping methodology was used to compare fish density by shoreline type across sampling dates. A bootstrapping method was used to account for the unbalanced sampling design. Bootstrapped resampling with replacement was conducted with 1500 replications. If significant differences were found, Holm-Sidak pairwise multiple comparison post hoc tests were performed (Holm 1979).

Water quality thresholds studied included DO concentrations $\leq 2.3 \mathrm{mg} \mathrm{O} / 2$ and $\leq 4.8 \mathrm{mg} \mathrm{O}_{2} / 1$ (inclusive of samples $\leq 2.3 \mathrm{mg} \mathrm{O} / \mathrm{l}$ ) and water temperature $\geq 27^{\circ} \mathrm{C}$. DO thresholds were based on federal and local EPA guidelines regarding fish growth and health (USEPA 2000). The temperature threshold was based upon analyzing the highest water temperature for which sample sizes remained adequately large on either side of the threshold (one-way and two-way ANOVA analyses of 26 and $28^{\circ} \mathrm{C}$ thresholds yielded comparable results). Salinity was not included in data analysis as it was not considered a stressor, with an adverse condition, for estuarine fishes. Mean fish density was calculated for all fish species (total catch) caught across each water condition threshold of interest.

A non-parametric one-way repeated measures ANOVA using a bootstrapping methodology was used to compare fish density across each shoreline type above and below water quality thresholds respectively.

Mean species richness was calculated for each shoreline type and water condition. Mean richness was calculated due to uneven sampling effort across all study factors, making total species richness inappropriate. Presence/absence proportions were calculated across each shoreline type and water condition for $F$. heteroclitus and $M$. menidia. These species were analyzed individually due to their high relative density, different life histories, and potentially differing responses to interaction between shoreline type and water conditions.

Non-parametric two-way ANOVAs were conducted to examine the density of all fishes, three species functional groupings, $F$. heteroclitus, and M. menidia across each shoreline (bulkhead, riprap, S. alterniflora, $P$. australis) and water condition threshold $\left(2.3 \mathrm{mg} \mathrm{O}_{2} / 1,4.8 \mathrm{mg} \mathrm{O} 2 / 1,27{ }^{\circ} \mathrm{C}\right)$. For analysis, sample density was categorically assigned to each threshold level (e.g., $>2.3 \mathrm{mg} \mathrm{O}_{2} / 1$ or $<2.3 \mathrm{mg} \mathrm{O}_{2} / 1$ ). Requisite parametric assumptions of normal distribution, equal variance, and equal sample sizes (sample sizes among all shoreline type/water condition blocks were unequal) were not met by the data, so non-parametric two-way ANOVAs using "aligned rank transformations" (Wobbrock et al. 2011) were used. The aligned rank transformation methodology allows for nonparametric analysis of factorial ANOVAs while calculating interactions. For each main effect or interaction, all responses are "aligned," a process that removes all effects from responses except the one for which alignment is being done. The aligned responses are then assigned ranks like those utilized in other non-parametric ANOVA methodologies. If significant differences were found, the Holm-Sidak method of pairwise multiple comparison post hoc test was performed using the Holm correction to account for repeated tests (Holm 1979). Based on pairwise comparisons, it was possible to determine where significant interactions indicated one 
shoreline type served as a "refuge" habitat in comparison with other shorelines. In cases of significant interactions, refuge shoreline types are utilized by fish at higher density rates (or at less reduced density rates) during adverse conditions. Adverse conditions included DO conditions $\leq 2.3$ and $\leq 4.8 \mathrm{mg} \mathrm{O}_{2} / 1$ as well as water temperature $\geq 27{ }^{\circ} \mathrm{C}$.

One-way and two-way ANOVA analyses were conducted for all species, for each individual species, and for three functional groups (species assignments to functional groupings are found in Table 2). Functional groupings of fish were created by summing species densities within each sampling event based on functional grouping assignments. Functional groupings were as follows:

- Littoral-demersal-Small-bodied bottom-oriented species that are frequently found in extremely shallow water $(<20 \mathrm{~cm})$ and forage on small littoral prey (polychaete worms, small crustaceans, small mollusks, small insects detritus, and plant matter).

- Planktivores - Species that forage on phytoplankton and zooplankton.

- Benthivore/piscivore-Large-bodied bottom-oriented species that forage on a suite of benthic invertebrates and small fishes.

QA/QC was performed on water quality data, DO concentration, and temperature, to remove erroneous data and outliers (primarily due to equipment fouling). Water quality data used for all analyses were taken from the data most immediately prior to the sampling event, either 15 or 30 min depending on data quality. Water quality measurements averaged across the hour, and 4-h period, prior to fish sampling were also analyzed using two-way ANOVA.

All statistical analyses were conducted using $\mathrm{R}$ (version 3.2.3)

\section{Results}

\section{Water Quality}

All tributary regions experienced hypoxia below both DO water quality thresholds and water temperatures $\geq 27{ }^{\circ} \mathrm{C}$ (Table 1). Hypoxic conditions were more frequent and extreme in upper tributary regions. DO during diel cycles ranged from $0 \mathrm{mg} \mathrm{O} / 1$ (anoxia) to $23.5 \mathrm{mg} \mathrm{O} / \mathrm{l}$ (super-saturated conditions) among all sampling stations in both years (Table 1). Severe diel-cycling hypoxia, ranging from $\leq 2.3 \mathrm{mg} \mathrm{O}_{2} / 1$ to $\geq 20 \mathrm{mg} \mathrm{O} / 1$ within a single diel cycle, began to occur frequently in late May in both 2009 and 2010. In both 2009 and 2010, the upper sampling regions of each tributary experienced the greatest percentage of time in hypoxia (Table 1). Mean monthly water temperature differed by a maximum of $6{ }^{\circ} \mathrm{C}$ at any individual sampling location (upper Pepper Creek (PCU), May vs. August) among months. Temperature was commonly higher at the upper region of each tributary. The percentage of temperature measurements $\geq 27^{\circ} \mathrm{C}$ was also highest in the upper section of each tributary (Table 1).

\section{Fish Assemblages-Shoreline Comparisons}

In total, 43,387 individuals in 20 fish species were collected at the 18 sampling stations over the two-summer study. Species caught included juvenile and adult estuary-resident and estuary-dependent species as well as transient marine fishes (Able and Fahay 1998, 2010; Table 2). Collections were dominated by $F$. heteroclitus ( $68 \%$ of total relative density). The ten species caught in the greatest mean density (Table 2) were found at all sampling locations (PCL, PCU, IRL, upper Indian River (IRU), IRLL) in all months except May. The remaining species caught in lower mean density (Table 2) were not collected at all sampling locations or in all months.

Table 1 Water quality characteristics by tributary region in Indian River and Pepper Creek during August through October 2009 and May through October 2010. See Fig. 1 for sampling station locations and "Materials and Methods" section for timing of water quality readings

\begin{tabular}{|c|c|c|c|c|c|c|c|}
\hline \multirow[b]{2}{*}{ Creek } & \multirow[b]{2}{*}{ Station } & \multirow[b]{2}{*}{ Year } & \multicolumn{2}{|c|}{ Temperature $\left({ }^{\circ} \mathrm{C}\right)$} & \multicolumn{3}{|c|}{$\mathrm{DO}\left(\mathrm{mg} \mathrm{O}_{2} / \mathrm{l}\right)$} \\
\hline & & & Range & $\begin{array}{l}\% \text { measurements } \\
\geq 27^{\circ} \mathrm{C}\end{array}$ & Range & $\begin{array}{l}\% \text { measurements } \\
\leq 4.8 \mathrm{mg} \mathrm{O}_{2} / 1\end{array}$ & $\begin{array}{l}\% \text { measurements } \\
\leq 2.3 \mathrm{mg} \mathrm{O}_{2} / 1\end{array}$ \\
\hline \multirow[t]{5}{*}{ Indian River } & \multirow[t]{2}{*}{ IRU } & 2009 & $20.1-32.8$ & 47 & $0-18.3$ & 44 & 16 \\
\hline & & 2010 & $20.4-35.6$ & 52 & $0-23.0$ & 62 & 28 \\
\hline & \multirow[t]{2}{*}{ IRL } & 2009 & $19.9-32.2$ & 40 & $0.2-14.5$ & 52 & 14 \\
\hline & & 2010 & $21.0-33.8$ & 42 & $0.1-17.6$ & 49 & 16 \\
\hline & IRLL & 2009 & $19.9-31.4$ & 39 & $0.1-13.7$ & 49 & 9 \\
\hline \multirow[t]{4}{*}{ Pepper Creek } & \multirow[t]{2}{*}{$\mathrm{PCU}$} & 2009 & $19.1-32.3$ & 61 & $0-23.5$ & 52 & 25 \\
\hline & & 2010 & $22.3-33.7$ & 67 & $0-18.4$ & 58 & 22 \\
\hline & \multirow[t]{2}{*}{ PCL } & 2009 & $19.3-32.0$ & 59 & $0.3-21.0$ & 41 & 8 \\
\hline & & 2010 & $22.8-33.9$ & 62 & $0.1-17.9$ & 44 & 14 \\
\hline
\end{tabular}


Table 2 Mean fish density (individuals $/ \mathrm{m}^{3}$ corrected for gear $Z$-scores) and standard error by shoreline type and species

\begin{tabular}{|c|c|c|c|c|c|c|c|}
\hline & $\begin{array}{l}\text { Life history } \\
\text { grouping }\end{array}$ & $\begin{array}{l}\text { Functional } \\
\text { grouping }\end{array}$ & S. alterniflora & P. australis & Riprap & Bulkhead & $\begin{array}{l}\text { Percent } \\
\text { of catch }\end{array}$ \\
\hline All fish species (mean density) & & & $101.28 \pm 2.72^{\mathrm{a}}$ & $24.92 \pm 0.75^{\mathrm{b}}$ & $17.85 \pm 0.35^{\mathrm{b}}$ & $16.69 \pm 0.69^{\mathrm{b}}$ & 100 \\
\hline Fundulus heteroclitus (mummichog) & $\mathrm{R}$ & L-D & $77.00 \pm 9.88^{\mathrm{a}}$ & $19.31 \pm 3.27^{b}$ & $10.07 \pm 1.03^{\mathrm{bc}}$ & $2.63 \pm 0.35^{\mathrm{c}}$ & 67.8 \\
\hline Brevoortia tyrannus (menhaden) & $\mathrm{D}$ & $\mathrm{P}$ & $11.47 \pm 6.93$ & $1.14 \pm 0.32$ & $1.74 \pm 0.7$ & $9.40 \pm 3.22$ & 14.8 \\
\hline Fundulus majalis (striped killifish) & $\mathrm{R}$ & L-D & $7.48 \pm 1.19^{\mathrm{a}}$ & $1.28 \pm 0.24^{\mathrm{ab}}$ & $0.90 \pm 0.15^{\mathrm{ab}}$ & $0.18 \pm 0.06^{\mathrm{b}}$ & 6.1 \\
\hline Menidia menidia (Atlantic silverside) & $\mathrm{D}$ & $\mathrm{P}$ & $1.05 \pm 0.19$ & $1.99 \pm 0.31$ & $2.51 \pm 0.85$ & $2.95 \pm 0.78$ & 5.3 \\
\hline Bairdiella chrysoura (silver perch) & $\mathrm{R}$ & $\mathrm{B} / \mathrm{P}$ & $1.47 \pm 0.53$ & $0.33 \pm 0.05$ & $1.02 \pm 0.20$ & $0.14 \pm 0.02$ & 1.8 \\
\hline $\begin{array}{l}\text { Cyprinodontidae variegatus (sheepshead } \\
\text { minnow) }\end{array}$ & $\mathrm{R}$ & L-D & $1.84 \pm 1.39$ & 0 & $0.04 \pm 0.01$ & $<0.01 \pm<0.01$ & 1.2 \\
\hline Mugil cephalus (striped mullet) & $\mathrm{D}$ & $\mathrm{P}$ & $0.12 \pm 0.02$ & $0.13 \pm 0.04$ & $1.00 \pm 0.62$ & $0.52 \pm 0.27$ & 1.1 \\
\hline Anchoa mitchilli (bay anchovy) & FD & $\mathrm{P}$ & $0.09 \pm 0.02$ & $0.17 \pm 0.08$ & $0.29 \pm 0.20$ & $0.65 \pm 0.23$ & 0.7 \\
\hline Leiostomus xanthurus (spot) & $\mathrm{D}$ & $\mathrm{B} / \mathrm{P}$ & $0.44 \pm 0.17$ & $0.26 \pm 0.11$ & $0.16 \pm 0.05$ & $0.05 \pm 0.01$ & 0.6 \\
\hline Cynoscion regalis (weakfish) & $\mathrm{D}$ & $\mathrm{B} / \mathrm{P}$ & $0.04 \pm<0.01$ & $0.07 \pm 0.02$ & $0.05 \pm 0.02$ & $0.02 \pm 0.01$ & 0.1 \\
\hline Morone saxatilis (striped bass) & $\mathrm{D}$ & $\mathrm{B} / \mathrm{P}$ & $0.04 \pm<0.01$ & $0.07 \pm 0.02$ & $0.01 \pm<0.01$ & $0.06 \pm 0.01$ & 0.1 \\
\hline Gobiosoma bosc (naked goby) & FD & L-D & $0.09 \pm 0.02$ & $0.06 \pm 0.01$ & $<0.01 \pm<0.01$ & $<0.01 \pm<0.01$ & 0.1 \\
\hline Paralichthys dentatus (summer flounder) & $\mathrm{D}$ & $\mathrm{B} / \mathrm{P}$ & $0.06 \pm 0.02$ & $0.03 \pm<0.01$ & $0.01 \pm<0.01$ & $0.02 \pm<0.01$ & 0.1 \\
\hline Trinectes maculatus (hogchoker) & $\mathrm{D}$ & $\mathrm{B} / \mathrm{P}$ & $0.01 \pm<0.01$ & $0.05 \pm 0.01$ & $0.02 \pm<0.01$ & $<0.01 \pm<0.01$ & $<0.1$ \\
\hline Caranx hippos (crevalle jack) & FD & $\mathrm{B} / \mathrm{P}$ & $0.07 \pm 0.01$ & $<0.01 \pm<0.01$ & 0 & $<0.01 \pm<0.01$ & $<0.1$ \\
\hline Mugil curema (white mullet) & $\mathrm{D}$ & $\mathrm{P}$ & $<0.01 \pm<0.01$ & $<0.01 \pm<0.01$ & $<0.01 \pm<0.01$ & $0.03 \pm<0.01$ & $<0.1$ \\
\hline Anguilla rostrata (American eel) & $\mathrm{D}$ & $\mathrm{B} / \mathrm{P}$ & $<0.01 \pm<0.01$ & $<0.01 \pm<0.01$ & $0.01 \pm<0.01$ & $<0.01 \pm<0.01$ & $<0.1$ \\
\hline Pomatomus saltatrix (bluefish) & FD & $\mathrm{B} / \mathrm{P}$ & $<0.01 \pm<0.01$ & $<0.01 \pm<0.01$ & $<0.01 \pm<0.01$ & $<0.01 \pm<0.01$ & $<0.1$ \\
\hline Opsanus tau (oyster toadfish) & $\mathrm{D}$ & $\mathrm{B} / \mathrm{P}$ & 0 & 0 & $<0.01 \pm<0.01$ & $<0.01 \pm<0.01$ & $<0.1$ \\
\hline Menidia beryllina (inland silverside) & $\mathrm{D}$ & $\mathrm{P}$ & 0 & 0 & $<0.01 \pm<0.01$ & 0 & $<0.1$ \\
\hline
\end{tabular}

Superscript letters indicate significant subgroupings based on bootstrapped one-way ANOVAs with Holm-Sidak pairwise comparisons to determine significant subgroupings. Life history groupings indicate species estuary life history relationship. Functional groupings are based on descriptions from Murdy et al. 1997

$R$-resident, $D$-obligate dependent, $F D$-facultative dependent (Able 2005), $L$ - $D$-ittoral-demersal, $P$-planktivore, $B / P$-benthivore/piscivore

Fish density differed among shoreline types, across all water conditions. Mean fish density was significantly greater (one-way RM ANOVA; $p<0.01 ; F=9.69$, d.f. $=3$ ) along $S$. alterniflora shorelines than at any other shoreline type (Table 2). Significantly greater densities of $F$. heteroclitus (one-way RM ANOVA; $p<0.01 ; F=10.93 ; d . f .=3$ ) were caught along $S$. alterniflora and the lowest density was along bulkhead. No significant differences in density among shoreline types were found for Brevoortia tyrannus, Bairdiella chrysoura, or M. menidia. Among the six species caught with greatest mean density, all were found in greater density along $S$. alterniflora shorelines than any other shoreline except for M. menidia which was most abundant along bulkhead (Fig. 2). $F$. heteroclitus comprised the greatest proportion of the catch at each shoreline except bulkhead where $B$. tyrannus dominated (Fig. 2).

\section{Fish Assemblages-Water Quality Threshold/Shoreline Interactions}

Significant results were found in non-parametric one-way repeated measures ANOVAs comparing fish density across shorelines above and below water quality thresholds. In water conditions above $2.3 \mathrm{mg} \mathrm{O} / 1$, significantly greater densities were found along $S$. alterniflora shorelines for all species $(p=0.015, F=7.44, d . f .=3)$, littoral-demersal $(p=0.074$, $F=7.03$, d.f. $=3)$, and $F$. heteroclitus $(p=0.036, F=7.94$, d.f. $=3$ ) (Fig. 3, Table 3). No significant differences were found among shoreline types in water conditions below $2.3 \mathrm{mg} \mathrm{O} / 1$ or above $4.8 \mathrm{mg} \mathrm{O}_{2} / 1$. In water conditions below $4.8 \mathrm{mg} \mathrm{O}_{2} /$ l, significantly greater mean fish densities were caught along $S$. alterniflora shorelines for all species ( $p=0.083, F=3.68$, d.f. $=3$ ), the littoral-demersal species group ( $p=0.034, F=9.31, d . f .=3$ ), and $F$. heteroclitus $(p=0.035, F=9.29$, d.f. $=3)$ (Fig. 3, Table 3). In water conditions above $27^{\circ} \mathrm{C}$, significantly greater mean fish densities were caught along $S$. alterniflora shorelines for all species $(p<0.01, F=8.26, d . f .=3)$ and $F$. heteroclitus $(p=0.029$, $F=7.70$, d.f. $=3$ ) (Fig. 3, Table 3). S. alterniflora shorelines were the only shoreline type at which any fish grouping or species was found in significantly greater density in conditions above or below adverse water condition thresholds.

Mean species richness was greater at all shoreline types when DO conditions were above $2.3 \mathrm{mg} \mathrm{O}_{2} / \mathrm{l}$, although the 

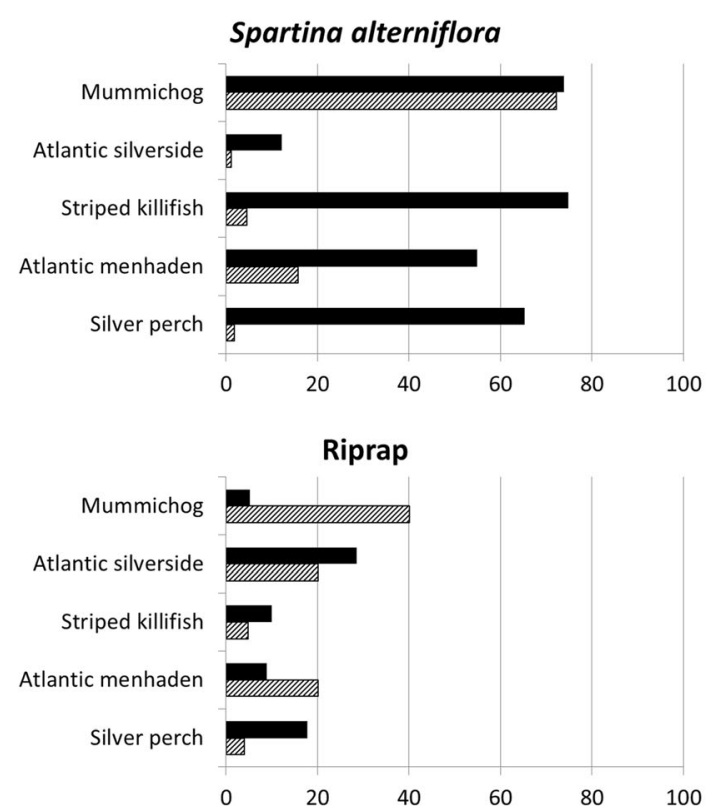

Fig. 2 Relative mean density (individuals $/ \mathrm{m}^{3}$ ) of the most abundant fish species sampled at each shoreline type in Indian River and Pepper Creek, tributaries of the Delaware Coastal Bays, from August through October 2009 and May through October 2010. Black bars represent the percentage of a given species' total catch (across all shoreline types) that was collected at the specified shoreline type; therefore, the longest black bars indicate the shoreline at which the species was particularly

magnitude of difference at each shoreline type was minimal (Fig. 4). S. alterniflora shorelines had the lowest reduction in mean species richness from conditions $>2.3 \mathrm{mg} \mathrm{O} / 1$ to $\leq 2.3 \mathrm{mg} \mathrm{O} / \mathrm{l}$, whereas bulkhead shorelines exhibited the greatest decline. Examining the $4.8 \mathrm{mg} \mathrm{O}_{2} / 1$ threshold, S. alterniflora and bulkhead shorelines had greater mean
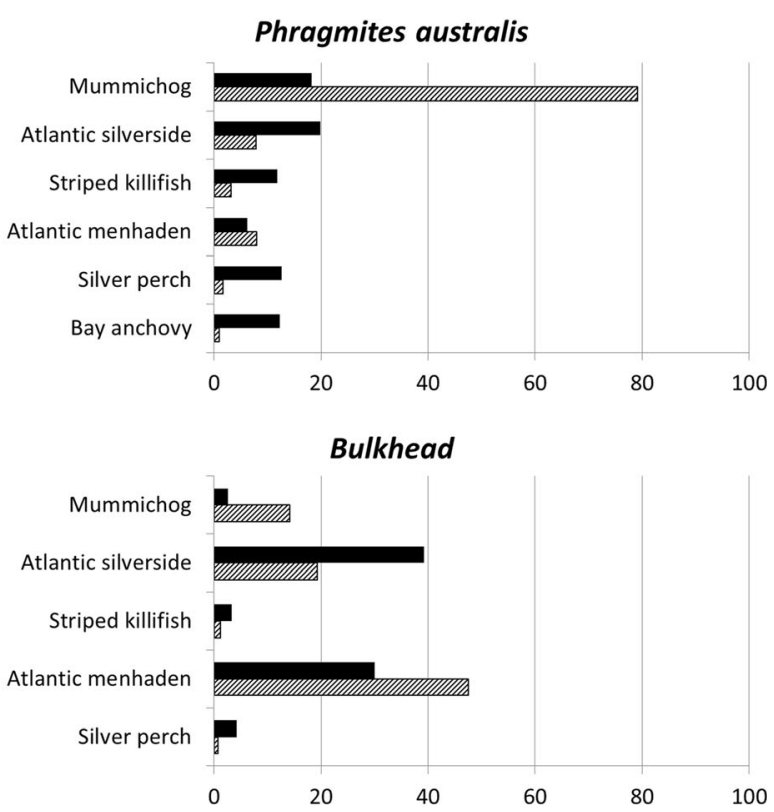

abundant (i.e., if a species had equal abundance along all four shoreline types, values for all four black bars would be at 25\%). Crosshatched bars represent the percentage of total catch for a given species at the given shoreline type; thus, the longest crosshatched bars indicate species that dominated the collections at the specified shoreline type (i.e., crosshatched bars within a panel sum to $100 \%$ )

species richness in conditions below the threshold. At the $27{ }^{\circ} \mathrm{C}$ water temperature threshold, only S. alterniflora shorelines experienced reduced mean species richness at water temperatures above the threshold (Fig. 4).

Species occurrence (presence/absence) rates also differed across water quality threshold and shoreline type (Table 4).

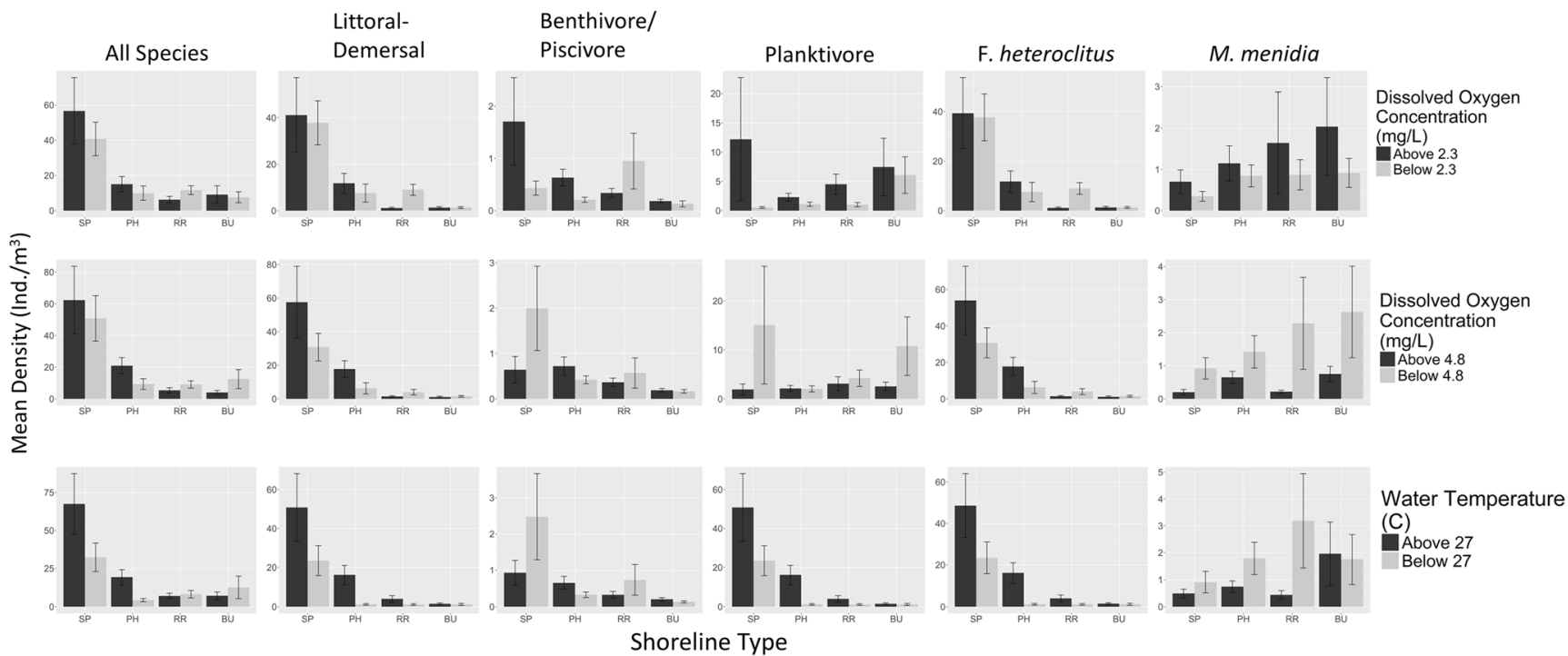

Fig. 3 Mean catch per unit effort (individuals $/ \mathrm{m}^{3}$ ) and standard error by shoreline type and water quality condition for total catch (All Species), the three functional groups as defined in Table 2, F. heteroclitus, and
M. menidia. Shoreline types are as follows: Spartina alterniflora-SP, Phragmites australis - $\mathrm{PH}$, riprap — RR, and bulkhead-BU 
Table 3 Shoreline type (Spartina alterniflora-SP, Phragmites australis - $\mathrm{PH}$, riprap - RR, and bulkhead-BU) with the greatest density caught above and below adverse water conditions, at each water quality threshold. Functional groupings are defined in Table 2. Shoreline codes in bold indicate density at that shoreline was significantly greater than at least one other shoreline type at the same threshold condition. Shoreline codes in bold and underlined indicate density at that shoreline was significantly greater than at all other shorelines at the same threshold condition

\begin{tabular}{|c|c|c|c|c|c|c|}
\hline \multirow[b]{2}{*}{ Grouping/species } & \multicolumn{2}{|c|}{ DO $2.3 \mathrm{mg} / \mathrm{l}$} & \multicolumn{2}{|c|}{ DO $4.8 \mathrm{mg} / 1$} & \multicolumn{2}{|c|}{ Temperature $27^{\circ} \mathrm{C}$} \\
\hline & $>2.3$ & $<2.3$ & $>4.8$ & $<4.8$ & $>27$ & $<27$ \\
\hline All species & SP & SP & SP & SP & SP & SP \\
\hline Littoral-demersal & SP & SP & SP & $\underline{\mathbf{S P}}$ & SP & SP \\
\hline Benthivore/piscivore & SP & $\mathrm{RR}$ & PH & SP & SP & SP \\
\hline Planktivore & SP & BU & $\mathrm{RR}$ & SP & SP & $\mathrm{BU}$ \\
\hline Fundulus heteroclitus (mummichog) & SP & SP & SP & $\underline{\mathbf{S P}}$ & SP & SP \\
\hline Menidia menidia (Atlantic silverside) & BU & BU & BU & $\overline{\mathrm{BU}}$ & BU & $\mathrm{RR}$ \\
\hline
\end{tabular}

Both $F$. heteroclitus and $M$. menidia were present in more samples, at all shoreline types, when DO during diel cycles remained above $2.3 \mathrm{mg} \mathrm{O}_{2} / 1$, with the exception of F. heteroclitus along bulkhead. Difference in presence/
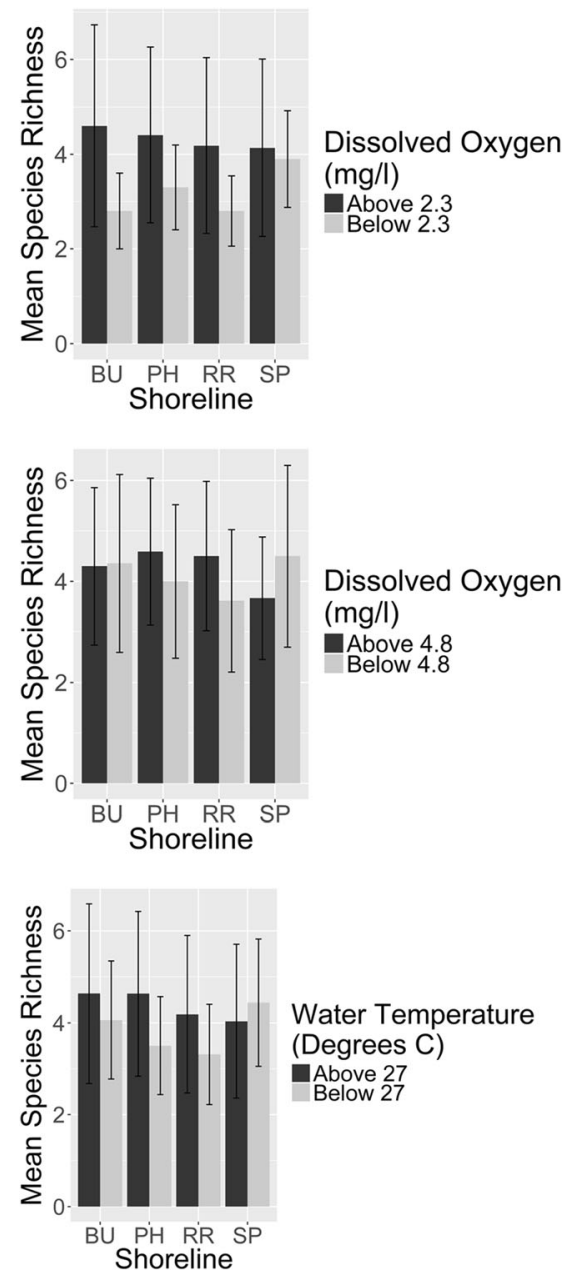

Fig. 4 Mean species richness and standard error by shoreline type and water quality threshold. Shoreline types are as follows: Spartina alterniflora-SP, Phragmites australis - $\mathrm{PH}$, riprap - RR, and bulkhead-BU absence for M. menidia occurred along armored shorelines, where they were present more frequently in higher DO conditions. The smallest differences in presence/absence rates above and below the $2.3 \mathrm{mg} \mathrm{O} / 1$ threshold occurred at $S$. alterniflora shorelines for $M$. menidia and at riprap for F. heteroclitus. At the $4.8 \mathrm{mg} \mathrm{O}_{2} / 1$ threshold, presence/ absence rates of $F$. heteroclitus and M. menidia varied minimally by shoreline type with little pattern. At the $27^{\circ} \mathrm{C}$ water temperature threshold, $F$. heteroclitus were much more commonly present in conditions exceeding the threshold, whereas $M$. menidia varied by shoreline type with little pattern (Table 4).

\section{Fish Assemblages-Two-Way ANOVA Water Quality Threshold/Shoreline Comparisons}

Results from aligned rank transformation two-way ANOVAs showed density differences across thresholds and species for water conditions present within $15 \mathrm{~min}$ prior to fish sampling (Table 5). All significant interactions that were found in twoway ANOVAs determined $S$. alterniflora to be the refuge habitat in comparison with other shoreline types. Density of all species together and for the littoral-demersal species grouping showed no significant interactions among either DO threshold $\left(2.3\right.$ or $\left.4.8 \mathrm{mg} \mathrm{O}_{2} / \mathrm{l}\right)$ and shoreline type. However, a significant interaction between the $27^{\circ} \mathrm{C}$ water temperature threshold and shoreline type was found for the density of all species together $\left(p=0.018, d_{\text {.f. }}=3, F=5.01\right)$ and littoraldemersal species ( $p=0.010, d . f .=3, F=5.91$ ). Pairwise comparisons revealed significant interaction between bulkhead and $S$. alterniflora and between riprap and $S$. alterniflora, with $S$. alterniflora being the refuge habitat in each comparison. No significant interaction between the $2.3 \mathrm{mg} \mathrm{O} / 1$ threshold and shoreline type was found for any species functional group or for either species of interest. No significant interactions among water quality thresholds and shoreline type were found for the planktivore species 
Table 4 Proportion of sampling events at which $F$. heteroclitus and $M$. menidia were present, by shoreline type and at each water quality threshold condition. Water quality thresholds include $\mathrm{DO} \leq 2.3 \mathrm{mg} \mathrm{O}_{2} / 1$ (DO 2.3), $\mathrm{DO} \leq 4.8 \mathrm{mg} \mathrm{O}_{2} / 1$ (DO 4.8), and temperature $\geq 27^{\circ} \mathrm{C}$ (Temp 27)

\begin{tabular}{|c|c|c|c|}
\hline \multirow[t]{2}{*}{ Shoreline } & \multirow[t]{2}{*}{ Water threshold } & \multicolumn{2}{|l|}{ Species } \\
\hline & & F. heteroclitus & M. menidia \\
\hline \multicolumn{4}{|l|}{ DO 2.3} \\
\hline \multirow[t]{2}{*}{ S. alterniflora } & Above & 0.76 & 0.65 \\
\hline & Below & 0.70 & 0.60 \\
\hline \multirow[t]{2}{*}{ P. australis } & Above & 0.75 & 0.91 \\
\hline & Below & 0.60 & 0.80 \\
\hline \multirow[t]{2}{*}{ Riprap } & Above & 0.64 & 0.85 \\
\hline & Below & 0.60 & 0.60 \\
\hline \multirow[t]{2}{*}{ Bulkhead } & Above & 0.62 & 0.87 \\
\hline & Below & 0.70 & 0.40 \\
\hline \multicolumn{4}{|l|}{ DO 4.8} \\
\hline \multirow[t]{2}{*}{ S. alterniflora } & Above & 0.72 & 0.44 \\
\hline & Below & 0.79 & 0.79 \\
\hline \multirow[t]{2}{*}{ P. australis } & Above & 0.76 & 0.94 \\
\hline & Below & 0.71 & 0.88 \\
\hline \multirow[t]{2}{*}{ Riprap } & Above & 0.63 & 0.75 \\
\hline & Below & 0.65 & 0.85 \\
\hline \multirow[t]{2}{*}{ Bulkhead } & Above & 0.65 & 0.80 \\
\hline & Below & 0.64 & 0.79 \\
\hline \multicolumn{4}{|l|}{ Temp 27} \\
\hline \multirow[t]{2}{*}{ S. alterniflora } & Above & 0.87 & 0.60 \\
\hline & Below & 0.41 & 0.75 \\
\hline \multirow[t]{2}{*}{ P. australis } & Above & 0.85 & 0.96 \\
\hline & Below & 0.50 & 0.79 \\
\hline \multirow[t]{2}{*}{ Riprap } & Above & 0.70 & 0.81 \\
\hline & Below & 0.50 & 0.75 \\
\hline \multirow[t]{2}{*}{ Bulkhead } & Above & 0.80 & 0.77 \\
\hline & Below & 0.56 & 0.88 \\
\hline
\end{tabular}

grouping (Table 5). Fishes in the benthivore/piscivore functional grouping had a significant interaction between the $4.8 \mathrm{mg} \mathrm{O}_{2} / 1$ and shoreline type $(p=0.014$, d.f. $=3$, $F=5.44)$ and between $27^{\circ} \mathrm{C}$ and shoreline type $(p=0.031$, d.f. $=3, F=4.16)$. In both cases, pairwise comparisons showed significant differences between $P$. australis and $S$. alterniflora, with $S$. alterniflora being the refuge habitat in each comparison. F. heteroclitus $(p=0.047$, d.f. $=3$, $F=3.58)$ had a significant interaction between the $4.8 \mathrm{mg} \mathrm{O}_{2} / 1$ and shoreline type, but pairwise comparisons did not find significant individual interactions among shoreline types for $F$. heteroclitus, suggesting a weak interaction. Significant interactions between the $27^{\circ} \mathrm{C}$ water temperature threshold and shoreline types were found for $F$. heteroclitus $(p<0.01, d . f .=3, F=6.98)$. Pairwise comparisons showed significant interaction between bulkhead and S. alterniflora, with $S$. alterniflora being the refuge habitat. No significant interactions among water quality thresholds and shoreline type were found for M. menidia (Table 5).

Water quality conditions occurring at rolling averages for 1 and $4 \mathrm{~h}$ prior to sampling were calculated to determine if fish reactions to water quality conditions at longer time frames prior to sampling resulted in stronger interactions than those seen at water quality conditions immediately prior to sampling. Similar results for two-way ANOVAs were found for water conditions averaged across the 1- and 4-h time period prior to fish sampling. Results from Welch's $t$ tests indicate no significant differences among water quality conditions for DO (15 min vs. $\sim 1 \mathrm{~h}: p=0.672 ; 15 \min$ vs. $\sim 4 \mathrm{~h}: p=0.871$ ) and temperature (15 min vs. $\sim 1 \mathrm{~h}: p=0.964 ; 15$ min vs. $\sim 4 \mathrm{~h}$ : $p=0.969)$ across these time frames.

\section{Discussion}

Estuary-resident fishes spend their entire life cycle within an estuary, utilizing shore-zone habitat for foraging, predator protection, and reproduction (Richards and Castagna 1970; Shenker and Dean 1979; Conover and Ross 1982; Able et al. 2003; Raichel et al. 2003). These species are adapted to the physiological demands of inhabiting temperate estuaries year-round, including those imposed by large fluctuations in temperature, DO, and salinity (Able and Fahay 1998). Likewise, estuary-dependent fish species spend a critical portion of their life cycle (larval and/or juvenile stages) in estuaries, often spanning several seasons (Fay et al. 1983a, b). Estuarine species, which comprise critical links in estuarine and marine food chains worldwide, have been shown to respond to physical changes in shore-zone habitats including shoreline armoring (Kneib 1997; Bilkovic and Roggero 2008). The degree to which these highly adaptable species are able to cope with changes in their environment may be an indicator of how the ecosystem as a whole will respond to shoreline development. Density of estuary-resident and estuary-dependent species (hereafter grouped together as estuarine) can reflect habitat quality (Szedlmayer and Able 1996; Rountree and Able 2007). As estuaries continue to be modified and degraded, additional processes such as competitive release and water quality tolerance (Lowe and Peterson 2014) can also contribute to species presence and density.

Among the most abrupt and permanent changes to estuarine environments are physical changes to marsh habitat as a result of human development, including shoreline armoring. Assessing the density and diversity of estuarine fish assemblages along various shore-zone environments has helped to elucidate the habitat quality provided by different shoreline types (Bilkovic and Roggero 2008; Balouskus and Targett 2016; Gittman et al. 2016a, b; Torre and Targett 2016). These studies, including the present research, have thoroughly 
Table 5 Results of two-way ANOVAs and Holm-Sidak pairwise comparisons of fish density (individuals $/ \mathrm{m}^{3}$ ) at pairs of shoreline types across water quality thresholds; for all species, the three functional groups as defined in Table 2, F. heteroclitus, and M. menidia. Statistical results of two-way ANOVAs comparing conditions above and below the thresholds indicated in the Water quality threshold column are presented in the Interaction $p$ value column. Refuge habitat shoreline types are utilized by fish at higher density rates (or at less reduced density rates) during adverse conditions. The bold shoreline type identified within the result matrix was identified in the pairwise comparison as being utilized at a significantly $(<0.05)$ greater density during adverse conditions defined as $\mathrm{DO} \leq 2.3 \mathrm{mg} \mathrm{O}_{2} / 1$ (DO 2.3), $\mathrm{DO} \leq 4.8 \mathrm{mg} \mathrm{O}_{2} / 1$ (DO 4.8), and temperature $\geq 27{ }^{\circ} \mathrm{C}$ (Temp 27). Shoreline types are as follows: Spartina alterniflora-SP, Phragmites australis- $\mathrm{PH}$, riprap- $\mathrm{RR}$, and bulkhead-BU. Cells in gray indicate no significant interaction term among water quality threshold and shoreline type for fish density was found. NA (not applicable) indicates a pairwise comparison with no significant interaction

\begin{tabular}{|c|c|c|c|c|c|c|c|c|}
\hline Species & $\begin{array}{c}\text { Water } \\
\text { quality } \\
\text { threshold }\end{array}$ & $\begin{array}{c}\text { Interaction } \\
p \text { value }\end{array}$ & SP-PH & SP-RR & SP-BU & PH-RR & PH-BU & RR-BU \\
\hline \multirow{3}{*}{ All species } & DO 2.3 & 0.688 & & & & & & \\
\hline & DO 4.8 & 0.143 & & & & & & \\
\hline & Temp 27 & 0.018 & NA & SP & SP & NA & NA & NA \\
\hline \multirow{3}{*}{$\begin{array}{l}\text { Littoral- } \\
\text { demersal }\end{array}$} & DO 2.3 & 0.317 & & & & & & \\
\hline & DO 4.8 & 0.072 & & & & & & \\
\hline & Temp 27 & 0.010 & NA & SP & SP & NA & NA & NA \\
\hline \multirow{3}{*}{ Planktivore } & DO 2.3 & 0.780 & & & & & & \\
\hline & DO 4.8 & 0.137 & & & & & & \\
\hline & Temp 27 & 0.990 & & & & & & \\
\hline \multirow{3}{*}{$\begin{array}{c}\text { Benthivore/ } \\
\text { piscivore }\end{array}$} & DO 2.3 & 0.323 & & & & & & \\
\hline & DO 4.8 & 0.014 & SP & $\mathrm{NA}$ & $\mathrm{NA}$ & $\mathrm{NA}$ & $\mathrm{NA}$ & $\mathrm{NA}$ \\
\hline & Temp 27 & 0.031 & SP & NA & NA & NA & $\mathrm{NA}$ & NA \\
\hline \multirow{3}{*}{$\begin{array}{c}F . \\
\text { heteroclitus }\end{array}$} & DO 2.3 & 0.403 & & & & & & \\
\hline & DO 4.8 & 0.047 & NA & SP & SP & NA & NA & NA \\
\hline & Temp 27 & 0.006 & NA & SP & SP & $\mathrm{NA}$ & $\mathrm{NA}$ & $\mathrm{NA}$ \\
\hline \multirow{3}{*}{ M. menidia } & DO 2.3 & 0.749 & & & & & & \\
\hline & DO 4.8 & 0.247 & & & & & & \\
\hline & Temp 27 & 0.742 & & & & & & \\
\hline
\end{tabular}

demonstrated the importance of native marsh grasses in serving as critical habitat in estuarine environments and the negative impact of armored shorelines, particularly bulkhead, on fish assemblages. Many other factors influence the occurrence and density of estuarine fishes in an estuary ecosystem including time of year, time of day, and distance from an ocean inlet (Able and Fahay 1998; Chant et al. 2000). Additional factors such as habitat characteristics that vary on hourly and hundred meter scales, like diel-cycling DO conditions and water temperature, have been shown to affect species occurrence and density as well (Blaber and Blaber 1980; Baltz et al. 1993; Tyler and Targett 2007; Stierhoff et al. 2009a). Understanding how both the physical characteristics of estuaries, including shore-zone habitats, and water quality interact to impact habitat quality for estuarine fish is much less well understood and its research may lead to more successful ecosystem management (Baltz et al. 1993).

Fish densities of $70 \%$ of all species caught in the present study were greater along vegetated shorelines than along armored shorelines. Across all water quality thresholds examined, S. alterniflora shorelines had the greatest total fish densities both above and below each threshold, indicating the native marsh grass is the most utilized habitat regardless of water condition. Species richness decreased at all shoreline types in conditions below the $2.3 \mathrm{mg} \mathrm{O} / 1 \mathrm{DO}$ threshold.
However, S. alterniflora shorelines exhibited the least decline in species and had the greatest mean species richness in conditions below (but not above) this threshold. Greatest mean species richness in conditions below $4.8 \mathrm{mg} \mathrm{O}_{2} / 1$ was also found at $S$. alterniflora. Additionally, results from two-way ANOVAs indicate a refuge effect provided by S. alterniflora compared with armored shorelines during water conditions exceeding $27^{\circ} \mathrm{C}$ for all species combined. This collection of results provides strong evidence that $S$. alterniflora provides greater habitat quality than armored shorelines and $P$. australis shores and serves as a refuge habitat by some species during adverse DO and temperature conditions. However, this conclusion is tempered as results from two-way ANOVAs examining interactions between the density of all fishes and DO conditions found no significant interactions, suggesting that neither S. alterniflora nor any of the shoreline types examined serve a significant refuge function during adverse DO conditions for the complete estuarine fish assemblage. These varying results imply that while $S$. alterniflora likely serves as a refuge habitat, the relationship between fish habitat use and water quality may be non-linear or not predominated by a threshold effect, particularly in the case of DO for all species. These interactions can be more closely examined by looking at functional species groupings and individual species reactions for adverse water conditions. 
Analysis of species functional groupings provides additional strong evidence supporting $S$. alterniflora serving as a refuge habitat during high temperature and low DO conditions. Littoral-demersal species, including F. heteroclitus, were found in greater densities at $S$. alterniflora shorelines under all water quality conditions and significantly so in conditions $<4.8 \mathrm{mg} \mathrm{O}_{2} / 1$. The life history characteristics of these species strongly tie them to marsh surface and edge habitats. In contrast, planktivore species utilize open water habitats for feeding and have less interaction with the marsh surface than littoral-demersal or benthivore species (Deegan 1990). However, planktivore species were found in the greatest density along $S$. alterniflora shorelines during adverse conditions $<4.8 \mathrm{mg} \mathrm{O} 2 / 1$ and $>27^{\circ} \mathrm{C}$. In seeing interactions not just only in species with strong life history connections with the marsh surface (littoral-demersal) but also in species more directly associated with open water habitats (planktivore), the overall importance of $S$. alterniflora as refuge habitat can be seen. And while the importance of $S$. alterniflora habitats may be stronger for certain species groupings than others, all three functional species groupings utilized $S$. alterniflora in greater densities during adverse water conditions $<4.8 \mathrm{mg} \mathrm{O}_{2}$ / and $>27^{\circ} \mathrm{C}$

The high relative density of $F$. heteroclitus along all shoreline types was expected given the large populations of this species that inhabit estuarine shores in the mid-Atlantic region of the USA (USFWS 1985; Rountree and Able 1992; Boutin and Targett 2013). F. heteroclitus also exhibit high physiological tolerances to changing oxygen and temperature conditions, such as those found in Pepper Creek and Indian River (Tyler et al. 2009) contributing to the species' dominance. These fish are important in salt marsh food webs, where they are instrumental in movement of organic material within and out of salt marsh ecosystems (Kneib 1986, 1997; Kneib and Wagner 1994). F. heteroclitus were the species found in greatest density at all shoreline types aside from bulkhead and a majority of all $F$. heteroclitus were caught at $S$. alterniflora shorelines. In addition to greater relative densities of mummichog being found along S. alterniflora shorelines than any other shoreline type across all water quality thresholds, the occurrence rate of $F$. heteroclitus in adverse water conditions was greatest at $S$. alterniflora shorelines across all three thresholds. F. heteroclitus have a very limited home range, suggesting very discrete relationships to the shoreline they inhabit (Lotrich 1975; Sweeny et al. 1998; Crum et al. 2017). How F. heteroclitus density responds to shoreline development and water quality thresholds may serve as a bellwether for other estuarine fauna. The disparity among densities along shoreline types may be due to the species preferential use of marsh pools, ditches, and depressions found on marsh surfaces at high tide. This marsh surface habitat, which is a certain proportion of the F. heteroclitus community, will leave for subtidal waters as the tide recedes, is greatest in S. alterniflora marshes (Able and Hagan 2003), and is reduced along $P$. australis marsh due to increased marsh elevation (Weinstein and Balletto 1999; Able and Hagan 2003; Able et al. 2003), and effectively non-existent along hardened shorelines. Weisberg and Lotrich (1982) demonstrated that $F$. heteroclitus require marsh surface habitat to supplement energy consumption. Generally, greater occurrence rates were found along unhardened shorelines regardless of water quality conditions. Significant interactions among shoreline type and water quality in two-way ANOVAs suggest that despite being tolerant of low DO conditions and high temperatures (Abraham 1985; Stierhoff et al. 2003), F. heteroclitus exhibit a degree of preferable habitat searching during adverse conditions.

M. menidia, a planktivorous species, is among the most abundant forage fish species in US mid-Atlantic estuaries (De Sylva et al. 1962; Richards and Castagna 1970; Able and Fahay 2010; Torre and Targett 2016). The importance of M. menidia as a food source for piscivores such as striped bass (Morone saxatilis), Atlantic mackerel (Scomber scombrus), bluefish (Pomatomus saltatrix), and other fishes is well documented (Bayliff 1950; Bigelow and Schroeder 1953; Schaefer 1970; Torre and Targett 2017). The greatest mean density of $M$. menidia was caught at bulkhead shorelines in this study. No shoreline type was dominated by M. menidia and only riprap shore-zones had $>20 \%$ of the total catch comprised of this species. Lower mean densities of M. menidia were caught in water conditions below the $2.3 \mathrm{mg} \mathrm{O}_{2} / 1$ threshold across all shoreline types suggesting strong avoidance of severe hypoxia. Despite these differences, results from twoway ANOVAs found no significant interactions among shoreline type and water conditions for M. menidia. As an estuarydependent species which utilizes estuarine habitats for spawning in the spring (Balouskus and Targett 2012) and inhabits offshore habitats during autumn and winter seasons (Fay et al. 1983a), it is possible that M. menidia utilize open water habitats more frequently and have less direct affinity for specific shoreline structures (either vegetated or armored) when inhabiting estuarine environments. Bulkhead structures have been shown to increase water depth at the land-water interface (Jennings et al. 1999; Peterson et al. 2000; Bilkovic et al. 2006), creating additional open water habitat. Differences between $F$. heteroclitus and M. menidia in mean density by shoreline type and responses to both DO and water temperature thresholds effectively show how different species utilize the same available shore-zone habitats in very different ways.

Results of this research show that estuary-resident and estuary-dependent species utilize $S$. alterniflora shorelines at greater density and occurrence rates than invasive $P$. australis or armored shorelines. Species density and richness declined in conditions $\leq 2.3 \mathrm{mg} \mathrm{O}_{2} /$ l. Total fish density, density of littoral-demersal species, and density of $F$. heteroclitus were 
greatest at $S$. alterniflora in all water conditions exceeding thresholds. Previous research has shown that fish density is reduced when DO drops below $4.8 \mathrm{mg} \mathrm{O}_{2} / 1$ and is severely reduced when DO drops below $2.3 \mathrm{mg} \mathrm{O}_{2} / 1$ (Eby and Crowder 2002; Tyler and Targett 2007). In the Neuse River Estuary of North Carolina, all ten species of fish studied (including pelagic and demersal estuary-dependent species) avoided areas with $\mathrm{DO}<2.0 \mathrm{mg} \mathrm{O}_{2} / 1$ (Eby and Crowder 2002). In laboratory studies, fishes (larval, juvenile, and adult) responded to oxygen gradients by moving upwards or laterally away from waters with physiologically stressful or potentially lethal DO concentrations and toward areas of higher DO (Breitburg 2002; Stierhoff et al. 2009b), a strategy that may be difficult for small estuarine fish species to employ over large areas due to low swim speeds and constricted home ranges. Results from this research suggest that the composition and location of the shore-zone fish assemblage in hypoxic estuarine systems may change with hourly changes in DO, and that shoreline structure may interact with diel-cycling hypoxia to effect habitat selection by estuarine fish.

Native $S$. alterniflora shorelines provide the greatest habitat quality in comparison with invasive and armored shorelines for a majority of species caught in this study as exhibited by mean density. This study demonstrates that native $S$. alterniflora shorelines may provide a degree of refuge for benthivore/piscivore species and $F$. heteroclitus during periods of low DO. S. alterniflora shorelines were also shown to serve as a refuge habitat during high water temperatures for the complete fish assemblage, benthivore/piscivore species, and littoral-demersal species including $F$. heteroclitus. The mechanisms by which $S$. alterniflora may serve as refuge habitat are varied. Macroalgal growth associated with $S$. alterniflora on the marsh surface and edge may increase DO in the immediate region. The complex physical structure provided by the close stems of $S$. alterniflora may provide predation protection or greater availability of immobile prey species in native marshes may contribute to refuge characteristics. Water/air temperature in the intertidal and shallow subtidal zone has been found to be significantly reduced $\left(\sim 2{ }^{\circ} \mathrm{C}\right.$ in the intertidal) in S. alterniflora habitats in comparison with hardened shorelines (Balouskus and Targett 2012). Regardless of the exact mechanisms by which $S$. alterniflora serves as refuge habitat, the conservation and management implications are clear and stress the importance of retaining stands of native marsh grasses. When possible, replacement of hardened shoreline with native marsh grasses such as S. alterniflora may contribute to the fish assemblage resilience to high temperatures and hypoxic conditions. Where erosion control structures are required, the installation of riprap-sill with native planting on the shoreward side or "living shorelines" may reduce the negative impact of riprap or other armoring on estuarine fish assemblages (Balouskus and Targett 2016, Gittman et al. 2016b).
This study confirmed the contrasting use of armored shorelines, invasive grass marshes, and native S. alterniflora marshes by estuarine fish as has been found in prior studies from the Chesapeake Bay (Bilkovic and Roggero 2008; Kornis et al. 2017), Gulf of Mexico (Peterson et al. 2000), Delaware coastal bays (Balouskus and Targett 2016), Hudson River (Strayer et al. 2012), and numerous other locations (Gittman et al. 2016a). New findings from this research have extended these prior studies by examining interactions among shoreline type habitat use and adverse water temperature and DO conditions. Fish density, occurrence rate, and species richness were all found to be affected by interactions among shoreline type and categorical water quality thresholds. These differences suggest variations in habitat quality provided by each shoreline type, exhibited through differences in shoreline-specific density, species richness, and occurrence rates across thresholds of DO and water temperature, suggesting a potentially non-linear or non-threshold relationship between shifting water conditions and relative shoreline habitat quality.

Acknowledgments We thank Brittany Schieler, Ed Hale, Katherine Bogue, Adriana Arujo, Maggie Miller, and Will Hale who all helped with the fieldwork. Patrick Gaffney and M. Conor McManus provided advice on statistical analyses. This research was supported by a grant from the NOAA, National Centers for Coastal Ocean Science, Center for Sponsored Coastal Ocean Research (award number NA09NOS4780219) to T.E. Targett. This is publication \#17-010 of the NOAA/CSCOR Mid-Atlantic Shorelines project.

Open Access This article is distributed under the terms of the Creative Commons Attribution 4.0 International License (http://creativecommons. org/licences/by/4.0/), which permits use, duplication, adaptation, distribution and reproduction in any medium or format, as long as you give appropriate credit to the original author(s) and the source, provide a link to Creative Commons license and indicate if changes were made.

\section{References}

Able, K.W. 2005. A re-examination of fish estuarine dependence: evidence for connectivity between estuarine and ocean habitats. Estuarine, Coastal and Shelf Science 64: 5-17.

Able, K.W., and M.P. Fahay. 1998. The first year in the life of estuarine fishes in the middle Atlantic Bight. New Brunswick: Rutgers University Press.

Able, K.W., and M.P. Fahay. 2010. Ecology of estuarine fishes: temperate water of the Western North Atlantic. Baltimore: The John Hopkins University Press.

Able, K.W., and S.M. Hagan. 2003. Impact of common reed, Phragmites australis, on essential fish habitat: influence on reproduction, embryological development, and larval abundance of mummichog (Fundulus heteroclitus). Estuaries 26: 40-50. 
Able, K.W., S.M. Hagan, and S.A. Brown. 2003. Mechanisms of marsh habitat alteration due to Phragmites: response of young-of-the-year mummichog (Fundulus heteroclitus) to treatment for Phragmites removal. Estuaries 26: 484-494.

Abraham, B. J. 1985. Species profiles: life histories and environmental requirements of coastal fishes and invertebrates (MidAtlantic) - mummichog and striped killifish. U.S. Fish Wildl. Serv. Biol. Rep. 82(11.40). U.S. Army Corps of Engineers, TR EL-82-4. 23 pp.

Balouskus, R.G., and T.E. Targett. 2012. Egg deposition by Atlantic silverside, Menidia menidia: substrate utilization and comparison of natural and altered shoreline type. Estuaries and Coasts 35: $1100-1109$

Balouskus, R.G., and T.E. Targett. 2016. Fish and blue crab density along a riprap-sill-hardened shoreline: comparisons with Spartina marsh and riprap. Transactions of the American Fisheries Society 145: 766-773.

Baltz, D.M., C. Rakocinski, and J.W. Fleeger. 1993. Microhabitat use by marsh-edge fishes in a Louisiana estuary. Environmental Biology of Fishes 36: 109-126.

Bayliff, W.H. 1950. The life history of the silverside, Menidia menidia (Linnaeus). Chesapeake Biological Laboratory 90: 1-27.

Bigelow, H.B. and W.C. Schroeder. 1953. Fishes of the Gulf of Maine. United States Fish and Wildlife Service Fisheries Bulletin 53577 pp.

Bilkovic, D.M., and M.M. Roggero. 2008. Effects of coastal development on near shore estuarine nekton communities. Marine Ecology Progress Series 358: 27-39.

Bilkovic, D.M., M.M. Roggero, C.H. Hershner, and K.J. Havens. 2006. Influence of land use on macrobenthic communities in near shore estuarine habitats. Estuaries and Coasts 29: 1185-1195.

Blaber, S.J.M., and T.G. Blaber. 1980. Factors affecting the distribution of juvenile estuarine and inshore fish. Journal of Fish Biology 17: 143162

Boutin, B.P., and T.E. Targett. 2013. Fish and blue crab assemblages in the shore-zone of tidal creeks in the Delaware Coastal Bays. Northeastern Naturalist 20 (1): 69-90.

Breitburg, D. 2002. Effects of hypoxia, and the balance between hypoxia and enrichment, on coastal fishes and fisheries. Estuaries 25: 767781.

Breitburg, D.L., L. Piehl, and S.E. Kolesar. 2001. Effects of low dissolved oxygen on the behavior, ecology and harvest of fishes: a comparison of the Chesapeake and Baltic systems. In Coastal hypoxia: consequences for living resources and ecosystems. Coastal and estuarine studies 58, ed. N.N. Rabalias and R.E. Turner, 241-267. Washington: American Geophysical Union.

Bricker, S.B., C.G. Clement, D.E. Pirhalla, S.P. Orlando, and D.R. Farrow. 1999. National estuarine eutrophication assessment: effects of nutrient enrichment in the nations estuaries. NOAA, National Ocean Service, Special Projects Office and the National Centers for Coastal Ocean Science. Silver Spring, MD: 71 pp.

Bricker, S.B., K.C. Rice, and O.P. Bricker III. 2014. From headwaters to coast: influence of human activities on water quality of the Potomac River Estuary. Aquatic Geochemistry 20: 291-323.

Brouha, P. 1993. Emulating Canada: recognizing existing aquatic and fish habitat areas as invaluable. Fisheries 18: 4.

Burns, D.C. 1991. Cumulative effects of small modifications to habitat. Fisheries 16: 12-17.

Chant, R.J., M.C. Curran, K.W. Able, and S.M. Glenn. 2000. Delivery of winter flounder (Pseudopleuronectes americanus) larvae to settlement habitats in coves near tidal inlets. Estuarine, Coastal and Shelf Science 51: 529-541.

Conover, D.O., and M.R. Ross. 1982. Patterns in seasonal abundance, growth and biomass of the Atlantic silverside, Menidia menidia, in a New England estuary. Estuaries 5: 275-286.
Crum, K.P., R.G. Balouskus, and T.E. Targett. 2017. Growth and movements of mummichogs (Fundulus heteroclitus) along armored and vegetated estuarine shorelines. In revision forthis $E \& C$ Special Issue.

Daiber, F.C. 1969. A summary of biological studies on Indian River and Rehoboth Bays with management recommendations. Dover: Delaware State Planning Office.

de Sylva, D.P., F.A. Kalber Jr. and C.N. Schuster Jr. 1962. Fishes and ecological conditions in the shore-zone of the Delaware River estuary, with notes on other species collected in deeper water. University of Delaware Marine Laboratory, Information Series, Publication 5: $1-164$.

Deegan, L.A. 1990. Effects of estuarine environmental conditions on population dynamics of young-of-the-year gulf menhaden. Marine Ecology Progress Series 68: 195-205.

Deegan, L.A., Hughes, J.E., \& Rountree, R.A. (2000). Salt marsh ecosystem support of marine transient species. In Concepts and Controversies in Tidal Marsh Ecology (eds M. Weinstein \& J. Kreeger), pp. 333-365. Kluwer Academic Publisher, The Netherlands.

Delaware Inland Bays Estuary Program (DIBEP). 1995. A comprehensive conservation and management plan for Delaware Inland Bays. Delaware Inland Bays Estuary Program, Rehoboth Beach, DE. 157 pp.

Diaz, R.J. 2001. Overview of hypoxia around the world. Journal of Environmental Quality 30: 275-281.

Diaz, R.J., and R. Rosenberg. 1995. Marine benthic hypoxia: a review of its ecological effects and the behavioral responses of benthic macrofauna. Oceanography and Marine Biology: An Annual Review 33: 245-303.

Diaz, R.J., and R. Rosenberg. 2008. Spreading dead zones and consequences for marine ecosystems. Science 321: 926-929.

Diaz, R.J., J. Nesterlode, and M.L. Diaz. 2004. A global perspective on the effects of eutrophication and hypoxia on aquatic biota. In Proceedings of the 7th International Symposium on Fish Physiology, Toxicology and Water Quality, Tallinn, Estonia, May 12-15, 2003, eds. GL Rupp, and MD White, 1-33. Athens Georgia, USA: US Environmental Protection Agency, Ecosystems Research Division, EPA 600/R-04/049.

Eby, L.A., and L.B. Crowder. 2002. Hypoxia-based habitat compression in the Neuse River Estuary: context-dependent shifts in behavioral avoidance thresholds. Canadian Journal of Fisheries and Aquatic Sciences 59: 952-965.

Fay, C.W., R.J. Neves, and G.B. Pardue. 1983a. Species profiles: life histories and environmental requirements of coastal fishes and invertebrates (mid-Atlantic) - Atlantic silverside. U.S. Fish and Wild1ife Service, Division of Biogical Services, FWS/OBS-82/ 11.10. U. S. Army Corps of Engineers, TR EL-82-4. 15 pp.

Fay, C.W., R.J. Neves, and G.B. Pardue. 1983b. Species profiles: life histories and environmental requirements of coastal fishes and invertebrates (mid-Atlantic) - striped bass. 1J.S. Fish and Wildlife Service, Division of Biological Services, FWS/OBS-82/11.8. 1J.S. Army Corps of Engineers, TR EL-82-4. 36 pp.

Gittman, R.K., S.B. Scyphers, C.S. Smith, I.P. Neylan, and J.H. Grabowski. 2016a. Ecological consequences of shoreline hardening: a meta-analysis. Bioscience 66: 763-773.

Gittman, R.K., C.H. Peterson, C.A. Currin, F.J. Fodrie, M.F. Piehler, and J.F. Bruno. 2016b. Living shorelines can enhance the nursery role of threatened coastal habitats. Ecological Applications 26: 249-263.

Halpin, P.M. 2000. Habitat use by an intertidal salt-marsh fish: trade-offs between predation and growth. Marine Ecology Progress Series 198: 203-214.

Hazelton, E.L., Mozdzer, T.J., Burdick, D.M., Kettenring, K.M. and Whigham, D.F., 2014. Phragmites australis management in the United States: 40 years of methods and outcomes. AoB Plants, 6 , p.plu001. 
Holm, S. 1979. A simple sequentially rejective multiple test procedure. Scandinavian Journal of Statistics 6: 65-70.

IPCC. 2014. In Climate change 2014: synthesis report. Contribution of Working Groups I, II and III to the fifth assessment report of the Intergovernmental Panel on Climate Change, ed. Core Writing Team, R.K. Pachauri, and L.A. Meyer. Geneva: IPCC 151 pp.

Jennings, M.J., M.A. Bozek, G.R. Hatzenbeler, E.E. Emmons, and M.D. Staggs. 1999. Cumulative effects of incremental shoreline habitat modification on fish assemblages in north temperate lakes. North American Journal of Fisheries Management 19: 18-27.

Kettenring, K.M., D.F. Whigham, E.L. Hazelton, S.K. Gallagher, and H.M. Weiner. 2015. Biotic resistance, disturbance, and mode of colonization impact the invasion of a widespread, introduced wetland grass. Ecological Applications 25: 466-480.

King, R.S., W.V. Deluca, D.F. Whigham, and P.P. Marra. 2007. Threshold effects of coastal urbanization on Phragmites australis (common reed) abundance and foliar nitrogen in Chesapeake Bay. Estuaries and Coasts 30: 469-481.

Kneib, R.T. 1986. The role of Fundulus heteroclitus in salt marsh trophic dynamics. American Zoologist 26: 259-269.

Kneib, R.T. 1997. The role of tidal marshes in the ecology of estuarine nekton. Oceanography and Marine Biology: An Annual Review 35: 163-220.

Kneib, R.T., and S.L. Wagner. 1994. Nekton use of vegetated marsh habitats at different stages of tidal inundation. Marine Ecology Progress Series 106: 227-238.

Kneib, R.T., A.E. Stiven, and E.B. Haines. 1980. Stable carbon isotope ratios in Fundulus heteroclitus (L.) muscle tissue and gut contents from a North Carolina Spartina marsh. Journal of Experimental Marine Biology and Ecology 46: 89-98.

Kornis, M.S., D. Breitburg, R. Balouskus, D.M. Bilkovic, L.A. Davias, S. Giordano, K. Heggie, A.H. Hines, J.M. Jacobs, T.E. Jordan, R.S. King, C.J. Patrick, R.D. Seitz, H. Soulen, T.E. Targett, D.E. Weller, D.F. Whigham, and J. Uphoff Jr. 2017. Linking the abundance of estuarine fish and crustaceans in nearshore waters to shoreline hardening and land cover. Estuaries and Coasts This issue.

Kramer, D.L. 1987. Dissolved oxygen and fish behavior. Environmental Biology of Fishes 18(2): 81-92.

Kwak, T.J., and J.B. Zedler. 1997. Food web analysis of southern California coastal wetlands using multiple stable isotopes. Oecologia 110: 262-277.

Lee, S.Y., R.J.K. Dunn, R.A. Young, R.M. Connolly, P.E.R. Dale, R. Dehayr, C.J. Lemckert, S. McKinnon, B. Powell, P.R. Teasdale, and D.T. Welsh. 2006. Impact of urbanization on coastal wetland structure and function. Austral Ecology 31: 149-163.

Lotrich, V.A. 1975. Summer home range and movements of Fundulus heteroclitus (Pisces: Cyprinodontidae) in a tidal creek. Ecology 56: 191-198.

Lowe, M.R., and M.S. Peterson. 2014. Effects of coastal urbanization on salt-marsh faunal assemblages in the northern Gulf of Mexico. Marine and Coastal Fisheries 6: 89-107.

Minchinton, T.E., J.C. Simpson, and M.D. Bertness. 2006. Mechanisms of exclusion of native coastal marsh plants by an invasive grass. Journal of Ecology 94: 342-354.

Murdy, E.O., R.S. Birdsong, and J.A. Musick. 1997. Fishes of Chesapeake Bay. Washington, D.C.: Smithsonian Institution Press.

Nixon, S.W. 1995. Coastal marine eutrophication: a definition, social causes and future concerns. Ophelia 41: 199-219.

Peterson, M.S., and M.R. Lowe. 2009. Implications of cumulative impacts to estuarine and marine habitat quality for fish and invertebrate resources. Reviews in Fisheries Science 17: 505-523.

Peterson, G.W., and R.E. Turner. 1994. The value of salt marsh edge vs. interior as a habitat for fish and decapods crustaceans in a Louisiana tidal marsh. Estuaries 17: 235-262.

Peterson, M.S., B.H. Comyns, J.R. Hendon, P.J. Bond, and G.A. Duff. 2000. Habitat use by early life-history stages of fishes and crusta- ceans along a changing estuarine landscape: differences between natural and altered shoreline sites. Wetlands Ecology and Management 8: 209-219.

Price, K.S. 1998. A framework for a Delaware inland bays environmental classification. Environmental Monitoring and Assessment 51: 285298.

Raichel, D.L., K.W. Able, and J.M. Hartman. 2003. The influence of Phragmites (common reed) on the distribution, abundance and potential prey of a resident marsh fish in the Hackensack meadowlands, New Jersey. Estuaries 26: 511-521.

Rakocinski, C.F., D.M. Baltz, and J.W. Fleeger. 1992. Correspondence between environmental gradients and the community structure of marsh-edge fishes in a Louisiana estuary. Marine Ecology Progress Series 80: 135-148.

Richards, C.E., and M. Castagna. 1970. Marine fishes of Virginia's eastern shore (inlet and marsh, seaside waters). Chesapeake Science 11: 235-248.

Rountree, R.A., and K.W. Able. 1992. Fauna of polyhaline subtidal marsh creeks in southern New Jersey: composition, abundance and biomass. Estuaries 15: 171-185.

Rountree, R.A., and K.W. Able. 2007. Spatial and temporal habitat use patterns for salt marsh nekton: implications for ecological functions. Aquatic Ecology 41: 25-45.

Rozas, L.P., and T.J. Minello. 1997. Estimating densities of small fishes and decapods crustaceans in shallow estuarine habitats: a review of sampling design with focus on gear selection. Estuaries 20: 199 213.

Schaefer, R.H. 1970. Feeding habits of striped bass from the surf waters of Long Island. New York Fish and Game Journal 17: 1-17.

Seber, G.A.F. 2002. The estimation of animal abundance and related parameters. Caldwell: Blackburn Press.

Seitz, R.D., R.N. Lipcius, N.H. Olmstead, M.S. Seebo, and D.M. Lambert. 2006. Influence of shallow-water habitats and shoreline development on abundance, biomass, and diversity of benthic prey and predators in Chesapeake Bay. Marine Ecology Progress Series 326: 11-27.

Shenker, J.M., and J.M. Dean. 1979. Utilization of an intertidal saltmarsh creek by larval and juvenile fishes: abundance, diversity and temporal variation. Estuaries 2: 154-163.

Stierhoff, K.L., T.E. Targett, and P.A. Grecay. 2003. Hypoxia tolerance of the mummichog: the role of access to the water surface. Journal of Fish Biology 63: 580-592.

Stierhoff, K.L., T.E. Targett, and J.H. Power. 2009a. Hypoxia-induced growth limitation of juvenile fishes in an estuarine nursery: assessment of small-scale temporal dynamics using RNA:DNA. Canadian Journal of Fisheries and Aquatic Science 66: 1033-1047.

Stierhoff, K.L., R.M. Tyler, and T.E. Targett. 2009b. Hypoxia tolerance of juvenile weakfish (Cynoscion regalis): laboratory assessment of growth and behavioral avoidance responses. Journal of Experimental Marine Biology and Ecology 381: S173-S179.

Strayer, D.L., S.E.G. Findlay, D. Miller, H.M. Malcom, D.T. Fischer, and T. Coote. 2012. Biodiversity in Hudson River shore-zones: influence of shoreline type and physical structure. Aquatic Sciences 74: 597-610.

Sweeny, J., L. Deegan, and R. Garritt. 1998. Population size and site fidelity of Fundulus heteroclitus in a macrotidal saltmarsh creek. Biological Bulletin 195: 238-239.

Szedlmayer, S.T., and K.W. Able. 1996. Patterns of seasonal availability and habitat use by fishes and decapods crustaceans in a southern New Jersey Estuary. Estuaries 19: 697-709.

Teo, S.L.H., and K.W. Able. 2003a. Habitat use and movement of the mummichog (Fundulus heteroclitus) in a restored salt marsh. Estuaries 26: 720-730.

Teo, S.L.H., and K.W. Able. 2003b. Growth and production of the mummichog (Fundulus heteroclitus) in a restored salt marsh. Estuaries 26: 51-63. 
Thayer, G.W., J.P. Thomas, and K.V. Koski. 1996. The habitat research plan of the National Marine Fisheries Service. Fisheries 2: 6-10.

Thomas, J.P. 1995. Remote sensing and relating coastal development to living marine resources and their habitats. Natural Areas Journal 15: 21-36.

Torre, M.P., and T.E. Targett. 2016. Nekton assemblages along riprapaltered shorelines in Delaware Bay, USA: comparisons with adjacent beach. Marine Ecology Progress Series 548: 209-218.

Torre, M.P., and T.E. Targett. 2017. Feeding by bluefish and weakfish along riprap-hardened shorelines: comparisons with adjacent sandy beach in Delaware Bay, USA. Transactions of the American Fisheries Society 146: 341-348.

Tyler, R.M. 2005. Dissolved oxygen conditions and composition of the juvenile finfish community in the Little Assawoman estuary. Delaware Department of Natural Resources and Environmental Control, Division of Water Resources, Dover.

Tyler, R.M., and T.E. Targett. 2007. Juvenile weakfish Cynoscion regalis distribution in relation to diel-cycling dissolved oxygen in an estuarine tributary. Marine Ecology Progress Series 333: 257-269.

Tyler, R.M., D.C. Brady, and T.E. Targett. 2009. Temporal and spatial dynamics of diel-cycling hypoxia in estuarine tributaries. Estuaries and Coasts 32: 123-145.

USEPA. 2000. Ambient aquatic life water quality criteria for dissolved oxygen (saltwater): Cape Cod to Cape Hatteras. Report no. EPA822-R-00-012, United States Environmental Protection Agency, Narragansett.

USFWS. 1985. Species profiles: life histories and environmental requirements of coastal fishes and invertebrates (mid-Atlantic): mummichog and striped killifish. Biological Report 82(11.40).
USGS. 2011. National assessment of shoreline change: historical shoreline change along the New England and Mid-Atlantic coasts. Open File Report: 2010-1118.

USGS. 2013. National Assessment of Shoreline Change Project. http:/ coastal.er.usgs.gov/shoreline-change/. Accessed 3 May 2013.

Valiela, I., J. McClelland, J. Hauxwell, P.J. Behr, D. Hersh, and K. Foreman. 1997. Macroalgal blooms in shallow estuaries: controls and ecophysiological and ecosystem consequences. Limnology and Oceanography 42: 1105-1118.

Waste, S.M. 1996. The NMFS Office of Habitat Conservation: protecting the habitats of living marine resources. Fisheries 21: $24-29$.

Weinstein, M.P. 1979. Shallow marsh habitats as primary nurseries for fish and shellfish, Cape Fear River, North Carolina. Fisheries Bulletin 77: 339-357.

Weinstein, M.P., and J.H. Balletto. 1999. Does common reed, Phragmites australis, affect essential fish habitat? Estuaries 22: 793-802.

Weisberg, S.B., and V.A. Lotrich. 1982. The importance of an infrequently flooded intertidal marsh surface as an energy source for the mummichog Fundulus heteroclitus: an experimental approach. Marine Biology 66: 307-310.

Windham, L., and L.A. Meyerson. 2003. Effects of common reed (Phragmites australis) expansions on nitrogen dynamics of tidal marshes of the northeastern U.S. Estuaries 26: 452-464.

Wobbrock, J.O., Findlater, L., Gergle, D. and Higgins, J.J. (2011). The aligned rank transform for nonparametric factorial analyses using only ANOVA procedures. Proceedings of the ACM Conference on Human Factors in Computing Systems (CHI '11). Vancouver, British Columbia (May 7-12, 2011). New York: ACM Press, pp. 143-146. 